THE WELLNESS LEVELS OF STUDENTS OF THE FACULTY OF SPORT SCIENCES: A COMPARATIVE EXAMPLE OF THE PRIVATE AND STATE UNIVERSITY ${ }^{(1)}$

\title{
THE WELLNESS LEVELS OF STUDENTS OF THE FACULTY OF SPORT SCIENCES: A COMPARATIVE EXAMPLE OF THE PRIVATE AND STATE UNIVERSITY
}

\author{
Suzan $D A L^{1}$, Hatice IIhan $O D A B A S^{2}$ \\ ${ }^{1}$ İstanbul Üniversitesi, Spor Bilimleri Fakültesi, İstanbul / Türkiye \\ ${ }^{2}$ Haliç Üniversitesi, Spor Bilimleri Fakültesi, İstanbul / Türkiye
}

ORCID ID: 0000-0002-7732-9846', 0000-0002-4578-5142²

Öz: Amaç: Araştırmanın amacı İstanbul'daki özel ve devlet üniversitelerinin spor bilimleri fakültesinde okuyan öğrencilerinin, toplam wellness ve wellness alt boyutlarını ölçmek, okul değişkenine göre wellness farklılıklarını belirlemektir. Genç nufusun yoğun olduğu Türkiye'de üniversite öğrencilerinin wellness ile ilgili farkındalıklarını artırmak, sağlıklı yaşam bilincini kazandırmak ve konu ile ilgili literature katkı sağlamak çalışmanın önemini göstermektedir. Yöntem: Araştırmada kullanılan wellness ölçeği Corbin ve arkadaşları tarafindan geliștirilmiş olup Türkçe uyarlaması Odabaş tarafindan yapılmıșțr. Ölçek dörtlü likert tipidir ve 5 alt boyutu (duygusal, fiziksel, zihinsel, sosyal, ruhsal wellness ) vardır. Verilerin değerlendirilmesinde spss 21 programı ullanılmıștır. Verilerin analizinde; alt ölçek puanlarının cinsiyet ve özel- devlet üniversitesi yönünden karşllaştırılmasında independent $\mathrm{t}$ testi ve tanımlayıc istatistikler kullanılmıştır. Bulgular: Araştırma evrenini istanbul'daki spor bilimleri fakiltesi öğrencileri oluşturmaktadır. Örneklem olarak bir devlet ve bir özel üniversite incelenmiștir. Araştırmaya yaş ortalamaları $22,5 \pm 2,47$, vücut ağırlıkları $71,86 \pm 12,26$, boyları, 177,19 $\pm 8,54$ ( 379 özel ünivesite, 176 devlet üniversitesi) olan toplam 555 öğrenci gönüllü olarak katılmıștır. Analizler sonucunda toplam wellness ve wellness alt boyutlarnnda cinsiyet ve üniversite değişkenine göre istatistiksel açıdan anlamlı farklılığa rastlanmamıștır. Sonuç: İstanbul'da devlet ve özel üniversitelerin spor bilimleri fakültesinde okuyan öğrencilerin toplam wellness değerlerinin yüksek olduğu tespit edilmiștir. Ayrıca bu öğrencilerin fiziksel wellness alt boyut puanlarının diğer alt boyutlardan daha yüksek olduğu sonucuna varılmıştır. Bu sonucun öğrencilerin fiziksel aktivite ağırlıklı eğitim almalarından kaynaklı olduğu düşünülebilir.

Anahtar Kelimeler: Wellness, Üniversite Öğrencisi, Fiziksel Wellness
Abstract: Aim: The aim of the study is measuring the dimensions of total wellness sub dimensions of wellness and determining differences according to college variables. Turkey's population is young. In such a country, to raise awareness of wellness, to gain awareness of healthy life and to contribute to the literature related to the subject is important. Method: Wellness Scale (WS) developed by Corbin et al. Wellness Scale (WS) Odabaş made Turkish adaptation. The wellness scale used in the study is a quaternary likert type and has 5 sub-dimensions (emotional, physical, mental, social, spiritual wellness). Each dimension consists of 3 questions. SPSS program was used to evaluate the data. In the analysis of data; independent t-test was used to compare gender and private-state university subscale scores. Findings: The research population is composed of the sports science students in Istanbul. As a sample, a state and a private university were examined. In total 555 (379 private universities, 176 state universities) volunteers participated in the study with a mean age of $22.5 \pm 2.47$, body weight $71.86 \pm 12.26$, height, $177.19 \pm 8.54$. As a result of the analyzes there were no statistically significant differences in total wellness and wellness subscales according to gender and university variables. Conclusion: Private and State university sport science students who study in İstanbul, have high level of wellness. In addition, it was concluded that the physical wellness subscale scores of these students were higher than the other subdimensions. It can be thought that this result is related to the physical activity training of the students.

Key Words: Wellness, University Students, Physical Wellness

Doi: 10.17363/SSTB.2019.31.5

(1) Corresponding Author: Suzan DAL, Istanbul University-Cerrahpasa, School of Foreign Languages, Avcilar, Istanbul/Turkey, suzan.dal@istanbul.edu.tr, Arrival Date / Received: 07.01.2019, Accepted / Accepted: 17.06.2019, Type of Article: (Application and Research) Conflict of Interest: None, Ethics Committee Report: Yes "Haliç University Non-Initiative Ethics Committee Report, No: 137 Decision No: 41" 
International Refereed Academic Journal of Sports, Health and Medical Sciences

April - May - June Issue: 31 Spring Summer Semester Year: 2019

Uluslararası Hakemli Akademik Spor Sağlık ve Tıp Bilimleri Dergisi

Nisan - Mayıs - Haziran Sayı: 31 İlbahar Yaz Dönemi Yıl: 2019 ID:435 K:527

ISSN Print: 2146-8508 Online 2147-1711

(ISO 18001-OH-0090-13001706 / ISO 14001-EM-0090-13001706 / ISO 9001-QM-0090-13001706 / ISO 10002-CM-0090-13001706) (TRADEMARK)

(2015/04315- 2015-GE-18972)

\section{INTRODUCTION}

Nowadays, most of the serious health problems consist of the life styles people follow and are described as life style diseases. In the USA and other developed countries, nearly half of the deaths at early ages are caused by problems related to life style (O'Donnell, 2001:49).

According to the statistics of World Health Organization (2013), the general causes of early deaths are heart attack, blood pressure, diabetes and obesity which are caused by life style in our country. These factors show that half of the early age deaths are caused by life style. One positive side of this situation is that by raising awareness of being healthy and protecting health and with changes in life style, people will have the chance of living more and a healthy old age. In other words, if people learn more about a healthy life and risks, they can live a healthier and longer life. As is seen, one's health and general well-being and life style are highly correlated (Doğan, 2004: 120-129).

Health is not having a disease or a disability and also being in a general wellness both socially and psychologically but this does not entirely meet the fact of being healthy. Wellness which has taken its place in our language contains all the extents of being healthy. The act of wellness aims to determine the factors that strengthen health and make alterations in life styles in that way (Doğan and Yıldırım, 2006: 49).

Wellness can also be explained as a lifelong process in which people feel good physically, socially and psychologically at a certain point in life. It involves controlling and minimising all the risk factors that cause illness and negative thoughts (Anspaugh et al., 2003; Wiley, 2014: 11-36). Wellness is also defined as a way of life orientated toward optimal health and wellbeing in which body, mind, and spirit are integrated by an individual to live more fully within the human and natural community (Myers, et al, 2000: 165-173). Whereas Adams, Bezner and Steinhardt (1997: 430436) defined wellness as a way of life people maintaining their physical, spiritual, physiological, social, emotional and intellectual existence consistently and in a balanced way and forming a life style in which these facts can have a healthy improvement.

Myers et al (2000: 165-173) defined people having high values in spirituality, sense of worth, sense of control, realistic beliefs, emotional awareness and coping, gender identity, self-care, sense of humour, nutrition, exercise, stress management, job satisfaction, hobbies, friendship, love and problem solving and creativity skills in the Wheel of Wellness are those who have high wellness ratings. They tried to define wellness by using those values 


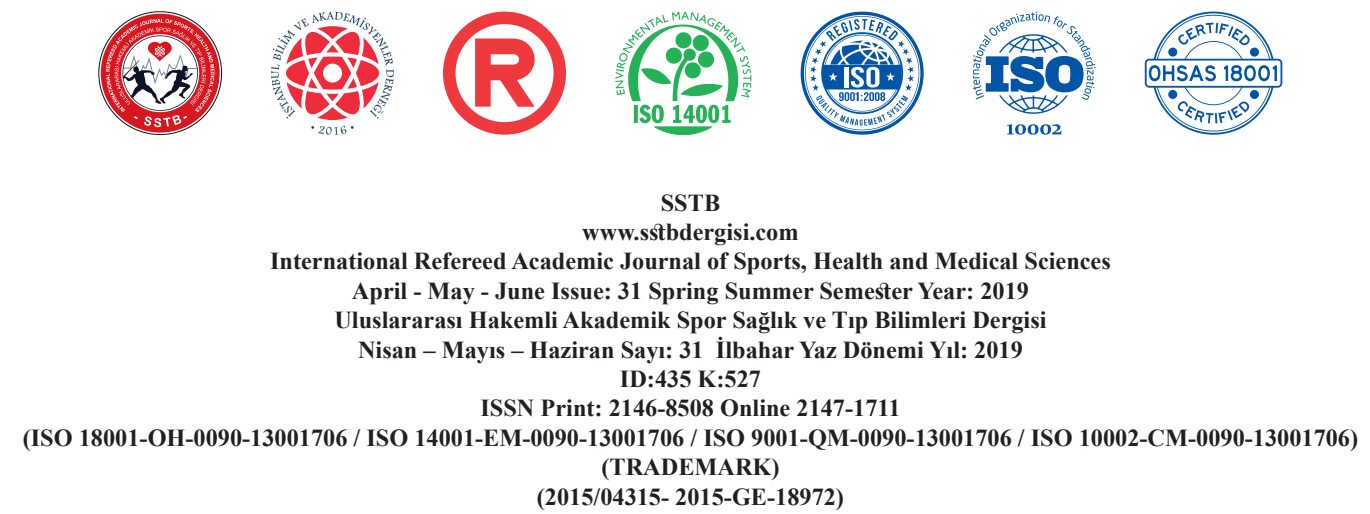

(2015/04315- 2015-GE-18972)

as base. In other words, they examined the situations that are necessary to make someone happy in those headings.

University students during their university education, where they are getting ready for adulthood and professional life, are expected to be people who can cope with their problems, participate actively, have good communication skills, be aware of factors that protect inherent and environmental physiological health and use those in their objective. It is important that they should be educated as an undaunted person who makes satisfactory relationships in his/her job and family life and takes pleasure in life and has hope concerning the future maintaining wellness both according to himself/herself and community (Gurgan, 2014: 19-35). The lifestyles people follow do not necessarily have to be their destiny. Necessary information to help individuals select a healthy lifestyle to increase their wellness can be provided with the help of suitable education programmes that will increase awareness (Doğan and Yıldırım, 2006:49). The university period, where habits and behaviour patterns for the rest of our life are formed is an important period in which people can gain awareness of a healthy life.

Guiding university students to form their life styles by giving them healthy living awareness will ensure that they will become health- ier in their upcoming lives and will reduce their risks of catching chronicle diseases. Most of the university students who are trying to maintain their active social lives during exams are not taking care of their personal health and wellness until they suffer from an inconvenience. Most of the university students should take the necessary steps in order to maintain a healthy life by continuing the physical activity they were doing during their studentship and by gaining awareness of being healthy (Higgins, 2009: 766-777).

Certain models were developed to determine the wellness of an individual with the aim of changing life styles of people and improving their wellness. In this study emotional, mental, physical, social and spiritual wellness of students were observed and Wellness selfperceptions scale was used in the study. In a developing country like Turkey where the young population is high, it is important to understand how the youth feel during their university period, to raise awareness and to form healthy life awareness. There are fewer studies about wellness for university youth in Turkey. That's why this study focuses on the wellness levels of public and private university students in the schools of physical education and sports.

Students of the schools of Physical Education and Sports in Turkey can specialise in three or four different fields of profession. These 
International Refereed Academic Journal of Sports, Health and Medical Sciences

April - May - June Issue: 31 Spring Summer Semester Year: 2019

Uluslararası Hakemli Akademik Spor Sağlık ve Tıp Bilimleri Dergisi

Nisan - Mayıs - Haziran Sayı: 31 İlbahar Yaz Dönemi Yıl: 2019 ID:435 K:527

ISSN Print: 2146-8508 Online 2147-1711

(ISO 18001-OH-0090-13001706 / ISO 14001-EM-0090-13001706 / ISO 9001-QM-0090-13001706 / ISO 10002-CM-0090-13001706) (TRADEMARK)

(2015/04315- 2015-GE-18972)

students are expected to have high wellness levels since sports sciences have a multidisciplinary structure. In this study it is expected to contribute to the Turkish and world literature by comparing the differences between the wellness levels of the students who study in the departments of sports management, training education and recreation education.

\section{AİM}

The aim of this study was to evaluate and compare the total wellness levels and emotional, physical, intellectual, social and spiritual wellness levels of the students who study in different departments of the Schools of Physical Education and Sports in public and private universities.

\section{MATERIAL and METHOD}

\section{The place where the survey took place and} the participants:

The study was conducted as a descriptive and analytical one in order to determine students wellness levels. The research population is composed of the sports science students in Istanbul. As a sample, a state and a private university were examined. This survey was carried out by means of the participation of
555 volunteer students (412 men, 143 women) studying in the schools of physical education and sports in one public and two private Universities in Istanbul.

\section{Research Material}

To assess the wellness perception of the participants, "Wellness self-perceptions" scale and personal information form was used. "Wellness self-perceptions" scale is a Likert type scale consisting of 4 strongly agree, 3 agree, 2 disagree, 1 strongly disagree.

\section{Method}

In the study "personal information form" was used to obtain the personal information and Wellness self-perceptions scale was used to examine the wellness perception of the participants.

Wellness self-perception scale: It is a scale formed of 15 questions with 5 main headings, 5 subscales and it is expected to be answered in 1 to 4 Likert type scale. Sub subscales are; emotional wellness, intellectual wellness, physical wellness, social wellness and spiritual wellness. Higher scores indicate a more positive self- rating in wellness behaviours. 
International Refereed Academic Journal of Sports, Health and Medical Sciences

April - May - June Issue: 31 Spring Summer Semester Year: 2019

Uluslararası Hakemli Akademik Spor Sağlık ve Tıp Bilimleri Dergis

Nisan - Mayıs - Haziran Sayı: 31 İlbahar Yaz Dönemi Yıl: 2019 ID:435 K:527

ISSN Print: 2146-8508 Online 2147-1711

(ISO 18001-OH-0090-13001706 / ISO 14001-EM-0090-13001706 / ISO 9001-QM-0090-13001706 / ISO 10002-CM-0090-13001706) (TRADEMARK)

(2015/04315- 2015-GE-18972)

\begin{tabular}{ll}
\multicolumn{1}{c}{ Wellness dimension scores } & Comprehensive wellness scores \\
\hline High Level Wellness 10-12, & High Level Wellness 50-60, \\
\hline Good Wellness 8-9, & Good Wellness 40-49 \\
\hline Marginal Wellness 6-7, & Marginal Wellness 30-39, \\
\hline Low Level Wellness Below 6, & Low Level Wellness Below 30.
\end{tabular}

Wellness Scale (WS) developed by Corbin et al. Wellness Scale (WS) Odabaş made Turkish adaptation. After the EFA, Kaiser-MeyerOlkin was found 0.86; and Cronbach Alpha internal consistency of total scale was found 0.86 .

\section{Statistical Methods}

Statistical analyses were conducted using the Statistical Package for Social sciences(SPSS) 21. Student T test was used to evaluate the differences of the wellness levels between the two universities.

\section{General quality of the research:}

Since the relationship between two different groups and more than two variables was investigated, relational screening model has been used.

\section{RESEACH RESCRICTIONS}

The fact that the study was conducted with students studying at the private and public universities in Istanbul constitutes a limitation in terms of the generalization of the results.

\section{RESEACH HYPOTHESES}

There is no difference in the wellness levels of the students of the sports sciences faculty who are studying in private and public universities. There is no difference in the total and sub-dimensions of the wellness of the male and female students at the faculty of sports sciences in private and public universities. 
SSTB

www.sstbdergisi.com

International Refereed Academic Journal of Sports, Health and Medical Sciences

April - May - June Issue: 31 Spring Summer Semester Year: 2019

Uluslararası Hakemli Akademik Spor Sağlık ve Tıp Bilimleri Dergisi

Nisan - Mayıs - Haziran Sayı: 31 İlbahar Yaz Dönemi Yıl: 2019 ID:435 K:527

ISSN Print: 2146-8508 Online 2147-1711

(ISO 18001-OH-0090-13001706 / ISO 14001-EM-0090-13001706 / ISO 9001-QM-0090-13001706 / ISO 10002-CM-0090-13001706) (TRADEMARK)

(2015/04315- 2015-GE-18972)

\section{RESULTS}

Table 1. The Evaluation of the Total Wellness and Wellness Sub Factors

\begin{tabular}{lllllll} 
& University name & $\mathrm{N}$ & $\mathrm{X}$ & $\mathrm{SS}$ & $\mathrm{T}$ & $\mathrm{P}$ \\
\hline \multirow{3}{*}{ Total Wellness point } & Haliç University & 379 & 50,4248 & 6,23665 &, 495 &, 621 \\
\cline { 2 - 7 } & İstanbul University & 176 & 50,1477 & 5,91471 &, 505 &, 614 \\
\hline \multirow{3}{*}{ Emotional Wellness } & Haliç University & 379 & 9,4327 & 1,65155 & 1,416 &, 157 \\
\cline { 2 - 7 } & İstanbul University & 176 & 9,2216 & 1,59707 & 1,434 &, 153 \\
\hline \multirow{3}{*}{ Intellectual Wellness } & Haliç University & 379 & 9,8918 & 1,53665 &, 039 &, 969 \\
\cline { 2 - 7 } & İstanbul University & 176 & 9,8864 & 1,49232 &, 040 &, 968 \\
\hline \multirow{3}{*}{ Physical Wellness } & Haliç University & 379 & 10,8470 & 2,12389 &,- 687 &, 492 \\
\cline { 2 - 7 } & İstanbul University & 176 & 10,9886 & 2,52980 &,- 645 &, 520 \\
\hline \multirow{3}{*}{ Social Wellness } & Haliç University & 379 & 10,3588 & 1,74058 &, 079 &, 937 \\
\cline { 2 - 7 } & İstanbul University & 176 & 10,3466 & 1,61751 &, 081 &, 935 \\
\hline \multirow{2}{*}{ Spiritual Wellness } & Haliç University & 379 & 9,8945 & 1,63928 & 1,258 &, 209 \\
\cline { 2 - 6 } & İstanbul University & 176 & 9,7045 & 1,68800 & 1,245 &, 214
\end{tabular}

Mean scores of the wellness test applied to the both two universities are shown in table 1. It has been seen that general wellness dimensions of the students of the two universities were higher (50-60) according to the values of the table 1 and the evaluation scale of the test. Also it has been seen that physical and social wellness scores were high besides emotional, spiritual and intellectual wellness dimensions were good. Table 1. It has been found that all wellness scores did not change and they were similar $(\mathrm{p}<0.05$ two tailed). (Table 1) 
SSTB

www.sstbdergisi.com

International Refereed Academic Journal of Sports, Health and Medical Sciences

April - May - June Issue: 31 Spring Summer Semester Year: 2019

Uluslararası Hakemli Akademik Spor Sağlık ve Tıp Bilimleri Dergis

Nisan - Mayıs - Haziran Sayı: 31 İlbahar Yaz Dönemi Yıl: 2019 ID:435 K:527

ISSN Print: 2146-8508 Online 2147-1711

(ISO 18001-OH-0090-13001706 / ISO 14001-EM-0090-13001706 / ISO 9001-QM-0090-13001706 / ISO 10002-CM-0090-13001706) (TRADEMARK)

(2015/04315- 2015-GE-18972)

Table 2. Comparing the Wellness Means of Female and Male Students

\begin{tabular}{|c|c|c|c|c|c|c|}
\hline & Sex & $\mathrm{N}$ & $\mathrm{X}$ & SS & $\mathrm{T}$ & $\mathrm{P}$ \\
\hline \multirow{2}{*}{$\begin{array}{l}\text { Total Wellness } \\
\text { Points }\end{array}$} & Female & 143 & 50,3944 & 6,28062 & ,148 &, 882 \\
\hline & Male & 412 & 50,3058 & 6,09125 & , 146 &, 884 \\
\hline \multirow{2}{*}{$\begin{array}{l}\text { Emotional Well- } \\
\text { ness }\end{array}$} & Female & 143 & 9,2113 & 1,64955 & $-1,310$ & ,191 \\
\hline & Male & 412 & 9,4199 & 1,63177 & $-1,303$ & , 194 \\
\hline \multirow{2}{*}{ Social wellness } & Female & 143 & 9,9155 & 1,54136 & ,265 &, 791 \\
\hline & Male & 412 & 9,8762 & 1,51448 & ,263 &, 793 \\
\hline \multirow{2}{*}{$\begin{array}{l}\text { Intellectual } \\
\text { Wellness }\end{array}$} & Female & 143 & 11,0352 & 2,76352 & ,877 & ,381 \\
\hline & Male & 412 & 10,8422 & 2,06155 &, 762 & ,447 \\
\hline \multirow{2}{*}{$\begin{array}{l}\text { Physical } \\
\text { Wellness }\end{array}$} & Female & 143 & 10,3732 & 1,74474 &, 172 & ,863 \\
\hline & Male & 412 & 10,3447 & 1,68798 &, 170 &, 865 \\
\hline \multirow{2}{*}{ Spiritual wellness } & Female & 143 & 9,8592 & 1,77689 &, 225 &, 822 \\
\hline & Male & 412 & 9,8228 & 1,61506 &, 215 &, 830 \\
\hline
\end{tabular}

According to the results of the two sample $t$ test used to determine if there were differences between the wellness points of the female and male students of the two universities, it has been found that there were no differences between the wellness score means of the female and male students ( $p>0,05$ two tailed). (Table 2

\section{DISCUSSION}

Wellness is a concept that consists of social, emotional, mental, spiritual and physical dimensions that help people contribute to their society and improve the quality of their lives. In other words wellness is a theoric dimension of explaining how a person feels.
In this study, wellness levels of Sport Sciences Students, who are studying at private or state universities in İstanbul, and other wellness components, are compared. In the study 5 parameters are being evaluated related to wellness. All wellness scores are evaluated separately.

According to the study, both university students' total wellness scores are high level and there is no meaningful difference between private or state university students. In addition, it was concluded that the physical wellness subscale scores of these students were higher than the other sub-dimensions.

In a study by Agopyan (2015: 145-156) on university students studying in physical edu- 


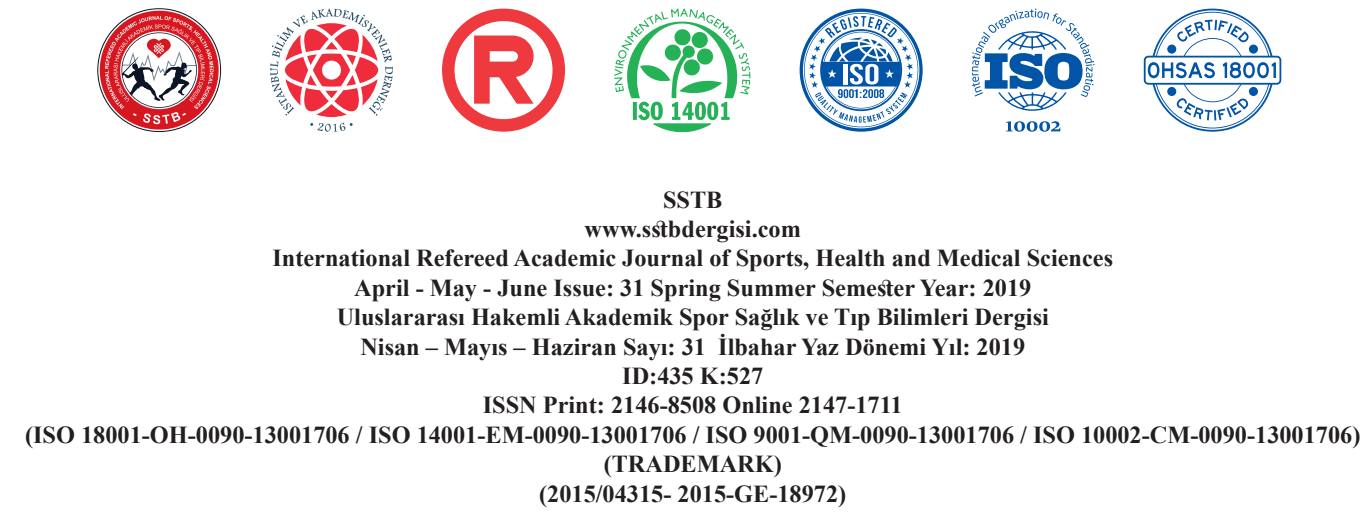

cation and sports colleges, it is thought that students regularly exercise sports and affect their physical health. The education of the students participating in our research is directly related to physical activity. The results of the study are similar to the results of the study of Agopyan (2015: 145-156)). In a study conducted on students studying at the Catholic Art School, a health-related parameter of nutrition, and exercise, were reported to be lower than sense of worth (LaFauntaine $\mathrm{J}$ et all 2012: 60-65). It supports the idea that there is a relationship between students' wellness levels and education that they recieve.

In line with these results, it is expected that the physical wellness levels of the students of the faculty of sports sciences are high. Roscoe (2009: 216-226.) shows in his study that if a person's physical level is high, that person is doing daily activities easier and confronts with medical problems lesser. Regular and adequate activities of individuals will increase their physical well-being. The increase in physical wellness will increase total wellness because physical wellness is an important component of total wellness (Corbin et all, 2009; Tremblay et al, 2014; 113-125, Corbin et all, 2014; 3327-3359 Stella et al., 2014: 3327-3359). Gaining physical wellness awareness for healthier societies will be easier to do through sports science faculty students.
In the study it has been found that there is no difference between female and male students' physical wellness levels. In addition, Agopyan's (2015: 145-156)) study shows that there is no difference in terms of gender. It can be considered that the reason why there is no difference in the wellness dimensions of male and female students is both groups have the same education. Both gender have same education. This sameness results developed physical wellness in a similar vein.

In our study, it was seen that the social wellness scores of the students studying in both universities were high. In our study, no differences were found in gender-specific comparisons between female and male students. Abdulhayoglu and colleagues (2012 :268-272) in their work in table tennis athletes reported that women and men athletes have high social wellness scores. Similar to our study, it was concluded that social wellness dimensions are high and there is no difference according to gender. In the study conducted by Bilge et al. (2010: 37-53) on university students' wellbeing, there was a difference between female and male participants and the social wellness of women was higher.

There was no significant difference in emotional wellness in the study on the students of the faculty of sports sciences. In addition, there was no significant difference between male and female groups. However, although 


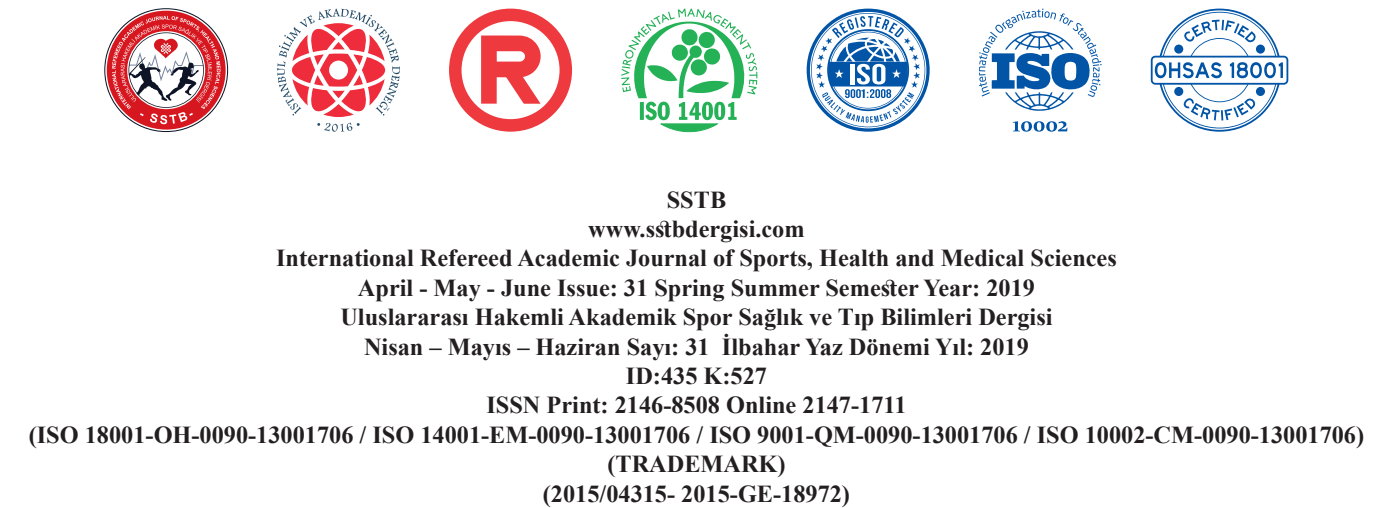

(2015/04315- 2015-GE-18972)

there was no statistically significant difference, the lowest score of the wellness sub-dimensions was in emotional wellness in both groups. LaFauntaine et al. (2012: 60-65) in the study of catholic liberal arts colleges of students in the "love" and "sense of worth" subtitles were found higher. It can be said that the emotional aspects of their education has positive effect.

In our study on university students, both university students generally had a good level of intellectual wellness. There was no significant difference when examined by gender.

As a result of the study, it was concluded that the spiritual wellness levels of the students were high and did not differ according to the gender variable. Because spiritual wellness in general affects all well-being, experts recommend that university students focus on life in a more mobile and more optimistic way with spiritual wellness programs (Troy, 2010; 165 173 Johson : 2007; 6-11. Said, 2006: 168175). It is thought that students who can control and shape their wellness health can lead their academic and personal lives positively (Patterson and Kline 2008; 49, Horton and Snyder 2009: 215-233).

\section{CONCLUSION}

As a result of the study, it was found that the wellness levels of private and public university sports sciences faculty students were high.
In addition, the physical well-being sub-dimension of the students was higher than the other wellness sub-dimensions. According to other studies, physical wellness is higher than others because of the students' departments. The lowest wellness points are emotional wellness. As a result, there was no difference in the wellness scores between male and female students.

\section{REFERENCES}

ADAMS, T.B., BEZNER, J.R., DRABBS, M.E., ZAMBARANO, R.J., STEINHARDT, M.A., (2010). Conceptualization and measurement of the spiritual and psychological dimensions of wellness in a college population. Journal of American college health, 48(4): 165-173

ADAMS, T., BEZNER, J., STEINHARDT, M., (1997). The conceptualization and measurement of perceived wellness: Integrating balance across and within dimensions. American Journal of health promotion, 11(3): 208-218.IRI

ABDULHAYOĞLU, B., KAYA, B., KONAR, N., (2012). Masa Tenisi Oyuncularının Esenlik Algıları. Selçuk University Journal Of Physical Education And Sport Science, 14(2): 268-272

AGOPYAN, A., (2015). Comparison of Body Composition, Cardiovascular Fitness, 
International Refereed Academic Journal of Sports, Health and Medical Sciences April - May - June Issue: 31 Spring Summer Semester Year: 2019

Uluslararası Hakemli Akademik Spor Sağlık ve Tıp Bilimleri Dergisi

Nisan - Mayıs - Haziran Sayı: 31 İlbahar Yaz Dönemi Yıı: 2019 ID:435 K:527

ISSN Print: 2146-8508 Online 2147-1711

(ISO 18001-OH-0090-13001706 / ISO 14001-EM-0090-13001706 / ISO 9001-QM-0090-13001706 / ISO 10002-CM-0090-13001706) (TRADEMARK)

Eating and Exercise Habits among University Students, Anthropologist, 19 (1): $145-156$

ANSPAUGH, D.J., HAMRICK, M.H., ROSATO, F.D., (2003). Wellness concepts and applications. New York, NY: McGraw Hill

BILGE, F., DOĞAN, N., GENÇTANIRIM, D., ARICIOĞLU, A., YALÇIN, I., et al., (2010). A study on multidimensional relationships. Eğitim Araştırmaları-Eurasian Journal of Educational Research, 41, 37-53

CORBIN, C.B., WELK, G., CORBIN, W., WELK, K.A., (2009).Concepts Of Fitness And Wellness: A Comprehensive Lifestyle Approach ( 8.Th Ed.). New York: McGraw Hill

CORBIN, C.B., WELK, J.G., CORBIN, R.W., WELK, A., (2014). Ket all Fundamental concepts of fitness and wellness(2006) Mc Graw Hill Comp USA, Int J Environ Res Public Health. 11(3): 3327-3359

CORBIN, C.B., (Ed.). (2005). Fundamental Concepts Of Fitness And Wellness. Boston, Mass.; Toronto: Mcgraw-Hill. Wang, W.-L., Lee, H.-L., \& Fetzer, S. J. (2006). Challenges and strategies of instrument translation. Western Journal of Nursing Research, 28(3), 310-321. doi:10.1177/0193945905284712

DOĞGN,T., (2004). ÜniversiteÖğrencilerinin Iyilik Halinin İncelenmesi, Hacettepe Üniversitesi Eğitim Fakültesi Dergisi, 30(30): 120-129.

G $\ddot{U} R \boldsymbol{G A N}, \quad$ U., (2014). Üniversite Öğrencilerinin Yılmazlık ve İyilik Halinin Bazı Değişkenlere Göre İncelenmesi. Education Sciences, 9(1), 19-35.

HIGGINS, J.W., LAUZON, L.L., YEW, A., BRATSETH, C., MORLEY, V., (2009). University Students' wellness-What Difference Can A Course Make?. College Student Journal, 43(3): 766-777

HORTON, B.W., SNYDER, C.S., (2009). Wellness: Its impact on student grades and implications for business. Journal of Human Resources in Hospitality \&Tourism, 8(2), 215-233.

JOHNSON, B., (2007). Examining perceptions of the health impact of spirituality in a university community, Vahperd Journal, 29(2): 6-11

LAFOUNTAINE, J., NEISEN, M., LARSEN, R., (2007). Wellness Factors in Firstyear College Students," Headwaters: The Faculty Journal of the College of Saint Benedict and Saint John's University: Vol. 24, 60-65 
International Refereed Academic Journal of Sports, Health and Medical Sciences April - May - June Issue: 31 Spring Summer Semester Year: 2019

Uluslararası Hakemli Akademik Spor Sağlık ve Tıp Bilimleri Dergisi

Nisan - Mayıs - Haziran Sayı: 31 İlbahar Yaz Dönemi Yıl: 2019 ID:435 K:527

ISSN Print: 2146-8508 Online 2147-1711

(ISO 18001-OH-0090-13001706 / ISO 14001-EM-0090-13001706 / ISO 9001-QM-0090-13001706 / ISO 10002-CM-0090-13001706) (TRADEMARK)

MYERS, J.E., SWEENEY, T.J., WITMER, J.M., (2000). The wheel of wellness counselling for wellness: A holistic model for treatment planning. Journal of Counseling\& Development, 78(3): 251-266

O'DONNELL, M.P., (2001). Our History and philosophy. American Journal of Health Promotion: 49

\section{PATTERSON, P., KLINE, T., (2008).Report} on postsecondary institutions as healthy settings. Findings from a study with college, institute and university students and student services administrators in Canada. Ottawa: Association of Canadian Community Colleges: 49

ROSCOE, L.J., (2009). Wellness: A review of theory and measurement for counselors. Journal of Counseling\& Development, 87(2): 216-226

SAID, I., (2006). Gardening As Restorative Environment For Children İn For Spirutial Wellness Theory And Practice. Journal Of Counseling And Development, 71, 168- 175

STELLA, K., MUTHURI, LUCY-JOY, M., WACHIRA A.G., LEBLANC, CLAIRE,
E., FRANCIS, MARGARET, S., et al., (2014)Temporal Trends And Correlates Of Physical Activity, Sedentary Behaviour, And Physical Fitness Among School-Aged Children In Sub-Saharan Africa: A Systematic Review, 11(3): 3327-3359

TREMBLAY, M.S., GRAY, C.E., AKINROYE, K., HARRINGTON, D.M., KATZMARZYK, P.T., et al., (2014). Physical activity of children: a global matrix of grades comparing 15 countries. Journal of physical activity and health, 11(s1): 113-125

TROY, B., ADAMS,JANET, R., BEZNER, P.T., MARY, E., DRABBS, E.D.T., ROBERT, J., et al., (2010) Conceptualization And Measurement Of The Spiritual And Psychological Dimensions Of Wellness In A College Population' Journal Of American College Health, 48(4): 165173

WILEY, L.F., (2014). Access to Health Care as an In centive for Healthy Behavior -An Assessment of the Affordable Care Act's Personal Responsibility for Wellness Reforms. Ind. Health L. Rev., 11, 36 